\title{
Harvest and postharvest brown rot of fruit in relation to early latent infection caused by Monilinia spp. in Hungary
}

\author{
Holb, I.J. \\ Centre for Agricultural Sciences, University of Debrecen 138 Böszörményi St., 4032 Debrecen, Hungary
}

\begin{abstract}
Summary: In this study, the effect of early latent infection caused by Monilina spp. on harvest and postharvest brown rot of sour cherry and peach was investigated. Two field experiments were performed in commercial orchards located at Eperjeske on sour cherry and at Siófok on peach in 2013 and 2014 in order to study the possible relationship between the incidence of early latent infection caused by Monilinia spp. and the incidence of harvest and postharvest brown rot. No latent infection was recorded at popcorn phanological stage of the trees at both locations. The maximum incidence was detected during the pit hardening period. There was a positive correlation between the incidence of latent infection and harvest or postharvest brown rot. The average incidence of latent infection during the crop season explained approximatelly $20 \%$ of the total variation in the incidence of postharvest brown rot.
\end{abstract}

Keywords: Monilinia spp., latent infection, postharvest brown rot, peach, sour cherry

\section{Introduction}

In Europe, brown rot in peaches and sour cherry is caused by mainly Monilinia laxa and M. fructigena (Holb, 2003ab). A third species, M. fructicola has also threat the European continent. These fungi cause losses by infecting blossom, flowers, and fruit during the preharvest, harvest, and postharvest periods (Xu \& Robinson, 2000; Holb, 2003a, Holb \& Schnabel, 2005).

Postharvest losses are typically more severe, especially when conditions are favourable for disease development (Hong et al. 1998, Larena et al. 2005, Gell et al., 2008). The most important cause of postharvest brown rot in peaches and sour cherries is M. laxa and M. fructigena in Hungary (Holb, 2003a). Conidia of both species produced mainly from overwintered fruit mummies and act as primary inoculum sources (Byrde \& Willetts 1977; Batra, 1991). When conditions are unfavourable, infections may remain latent until conditions become favourable for disease expression, at which point fruit rot ensues (Byrde \& Willetts 1977). Fruit growth stage also plays an important role in disease expression (Luo et al. 2001a; Xu et al. 2007; Gell et al., 2008). Latent infections caused by $M$. laxa have been detected in nectarines and plums (Fourie \& Holz 2003a; Gell et al., 2008). Xu et al. (2007) showed a high correlation between the incidence of caused by M. laxa and M. fructigena and latent infection in cherries. Several authors showed the same relationships for M. fructicola in immature plum and nectarine (Emery et al. 2000; Luo \& Michailides 2001; Northover \& Cerkauskas 1994).
The aim of this study was to investigate the effect of early latent infection caused by Monilina spp. on harvest and postharvest brown rot of sour cherry and peach.

\section{Materials and methods \\ Orchard site and experimental design}

The experiment was carried out in an organic orchard located at Eperjeske, Hungary. The orchard was planted with cultivars Mutsu, Jonathan, Prima on M26 rootstocks in 1997. The distance between rows was $5 \mathrm{~m}$, and the distance between trees within a row was 2 . The orchard was treated according to the Hungarian Organic Growing Guidelines derived from the IFOAM guidelines. The micro-area based spatial experiment was set in 2013 and 2014.

\section{Data collection}

Incidence of latent infection at different growth stages and the incidence of postharvest brown rot were performed in two commercial orchards located at Eperjeske on sour cherry and at Siófok on peach in 2013 and 2014 The cultivars grown in the orchards were sour cherries cvs. Újfehértói fürtös and Érdi bőtermö, and peach cv. Redhaven. Ten replicates were selected andomly in both orchards (each replicate contains 5 trees). Disease management of the trees followed integrated management practices. The incidence of latent infection was assessed at the following phanological stages: $\mathrm{BBCH}=55, \mathrm{BBCH}=76, \mathrm{BBCH}=79$, and 10 days before 
harvest $(\mathrm{BBCH}=86)$ according to Meier et al. (1994). Ten blossoms or fruit per tree without visible signs of infection with Monilinia spp. were collected from the orchards and studied further in laboratory according to the following methods. Fruit was surface disinfected (70\% ethanol, $20 \mathrm{~s}$; $0.5 \% \mathrm{NaOCl}, 4 \mathrm{~min}$ ). The fruit was then rinsed for $1 \mathrm{~min}$ in sterile distilled water. The disinfected fruit was dipped in a solution of $6 \mathrm{~g} \mathrm{l}^{-1}$ of paraquat for $1 \mathrm{~min}$. Then fruit was again rinsed for $3 \mathrm{~min}$ in sterile distilled water. It was then incubated in humid chambers at $22 \pm 2^{\circ} \mathrm{C}$ with fluorescent lighting at a 16-h photoperiod for 6 to 12 days. Latent infection with Monilinia spp. was recorded when sporulation on peach and sour cherry appeared.

The incidence of harvest and postharvest brown rot was evaluated on ten fruit per replicate picked at harvest. The fruit was placed in humidity chambers incubated at $22 \pm 2^{\circ} \mathrm{C}$ with fluorescent light with a 16-h photoperiod for 6 days. Brown rot assesment were made after 0 and 6 days incubation.

\section{Data analysis}

The incidence of latent infection was calculated for each orchard and the four phenological date, and a latent infection curve was prepared obtained. In addition correlation analyses were performed to analyse the relationship between the incidence of brown rot symptoms and the incidence of latent infection.

\section{Results}

\section{Disease incidence latent infection}

Latent infection was not recorded at the earliest stage (BBCH 55) in either orchard. The incidence of latent infection increased during $\mathrm{BBCH} 76$, and it remained constant until $\mathrm{BBCH}$ 79. The incidence of latent infection increased at the pre-harvest $(\mathrm{BBCH}$ 86) stage in both orchards (Fig. 1). The mean incidence of latent infection and the incidence of postharvest were the largest in the peach orchard in 2014 while the lowest in the sour cherry orchard in 2013 (Table 1). The highest values were 9.3 and $29.4 \%$ as well as the lowest 3.1 and $6.8 \%$, respectively.

\section{Correlation analyses}

The mean incidence of latent infection showed a significant correlation with the incidence of latent infection at the different sampling dates and fruit rot at harvest and post-harvest (Table 2). The incidence of latent infection at BBCH76 and BBCH79 showed no significant correlation with the incidence of harvest and postharvest brown rot (Table 2). The strongest correlations were obtained between the mean incidence of latent infection and the incidence of harvest fruit rot and between the mean incidence of latent infection and the incidence of postharvest fruit rot and between the incidence of harvest fruit rot and the incidence of post-harvest brown rot. ( $\mathrm{r}=0.77,0.78$ and 0.79 , respectively).

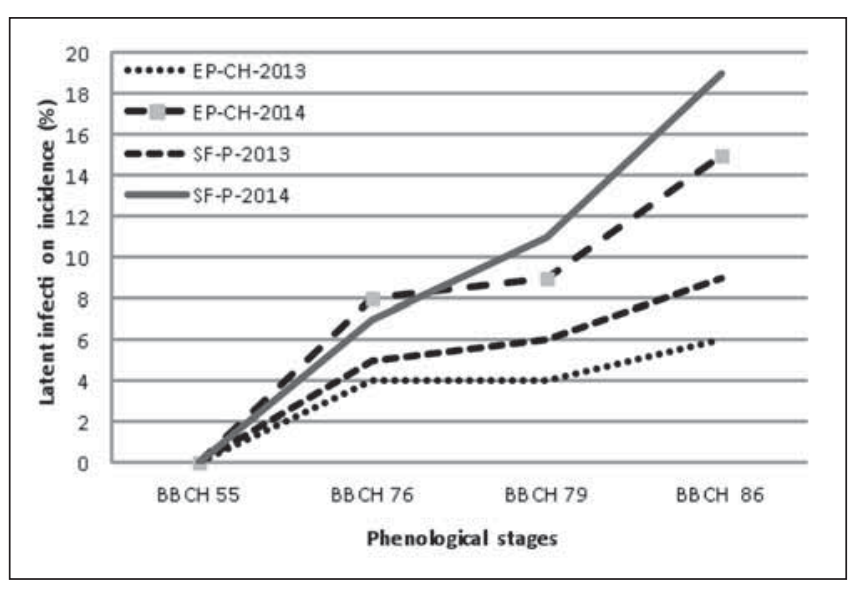

Figure 1 Percentage of latent infection caused by Monilinia spp. in tow fruit orchards (Eperjeske EP and Siófok SF) on sour cherry $(\mathrm{CH})$ and peach (P) in 2013 and 2014.

Table 1. Mean latent incidence (MLI \%), fruit rot incidence at harvest (FRH, \%) and fruit rot incidence at postharvest (FRPH, \%) caused by Monilinia spp. in sour cherry (Eperjeske 2013 and 2014) and peach (Siófok 2013 and 2014)

\begin{tabular}{|l|c|c|c|}
\hline \multicolumn{1}{|c|}{ Orchard, year, and fruit } & MLI (\%) & FRH (\%) & FRPH (\%) \\
\hline Eperjeske, 2013, cherry & 3.1 & 5.4 & 6.8 \\
\hline Eperjeske, 2014, cherry & 7.6 & 13.6 & 18.2 \\
\hline Siófok, 2013, peach & 4.2 & 9.1 & 10.8 \\
\hline Siófok, 2014, peach & 9.3 & 15.1 & 29.4 \\
\hline
\end{tabular}

Table 2. Correlation coefficients between latent infection at different phenological stages and harvest and posthavest fruit rot caused by Monilinia spp. in sour cherry (Eperjeske 2013 and 2014) and peach (Siófok 2013 and 2014). Significant $r$ values $(P \leq 0.05)$ are in bold

\begin{tabular}{|l|l|l|l|l|l|l|}
\hline & $\begin{array}{c}\text { BBCH76 } \\
(\%)\end{array}$ & $\begin{array}{c}\text { BBCH79 } \\
(\%)\end{array}$ & $\begin{array}{c}\text { BBCH86 } \\
(\%)\end{array}$ & \multicolumn{1}{|c|}{$\begin{array}{c}\text { MLI } \\
(\%)\end{array}$} & $\begin{array}{c}\text { FRH } \\
(\%)\end{array}$ & FRPH (\%) \\
\hline BBCH76 (\%) & 1 & $\mathbf{0 . 5 7}$ & $\mathbf{0 . 5 8}$ & $\mathbf{0 . 6 1}$ & 0.11 & 0.05 \\
\hline BBCH79 (\%) & 1 & $\mathbf{0 . 6 5}$ & $\mathbf{0 . 6 4}$ & 0.32 & 0.12 \\
\hline BBCH86 (\%) & & & 1 & $\mathbf{0 . 6 8}$ & $\mathbf{0 . 5 2}$ & 0.36 \\
\hline MLI (\%) & & & & 1 & $\mathbf{0 . 7 8}$ & $\mathbf{0 . 7 7}$ \\
\hline FRH (\%) & & & & & 1 & $\mathbf{0 . 7 9}$ \\
\hline FRPH (\%) & & & & & & 1 \\
\hline
\end{tabular}

\section{Discussion}

This study demonstrated a positive relationship between the incidence of latent infection by Monilinia spp. and the incidence of post-harvest brown rot and between the incidence of latent infection by Monilinia spp. and the incidence of latent infection at the different sampling dates in sour cherry and peach. The most prevalent species isolated from brown rot in sour cherry and peach fruit was M. laxa. Monilinia fructigena is mainly associated with brown 
rot of pome fruit (van Leeuwen et al. 2000; Holb, 2003, Holb \& Scherm, 2007, 2008; Holb et al., 2011). Positive relationships between incidences of latent infection and brown rot at harvest or during the post-harvest period have been previously described for other species and hosts such as M. fructicola and peaches (Emery et al. 2000), prunes (Luo et al. 2001a, b; 2003), and plums (Northover \& Cerkauskas 1994), and M. laxa and cherries (Xu et al. 2007) and M. laxa on peaches (Gell et al., 2008).

This study showed that a 3-9\% average incidence of latent infection from the fruit set to preharvest periods may lead to more than $6-30 \%$ of postharvest brown rot. The pattern of latent infection observed in sour cherries and peaches in our study has similarities to that in peaches with M. laxa (Gell et al., 2008) and in prunes infected with $M$. fructicola, especially during the pre-harvest period (Biggs \& Northover 1988ab; Luo et al. 2001b, 2003). In these studies, the maximum latent infection incidence occurred during the pre-harvest; in some orchards a second peak was detected at pit hardening.

\section{Conclusions}

Present results demonstrated that latent infection can occur and may be taken into consideration in disease management programmes in Hungary. Although brown rot may not be severe at harvest, but it could develop later because of the high incidence of latent infection.

\section{Acknowledgements}

This research was supported by grants of the Hungarian Scientific Research Fund (K108333).

\section{References}

Batra, L. R. (1991): World species of Monilinia (Fungi): their ecology, biosystematics and control. Mycologia Memoir No. 16, J. Cramer, Berlin, 246 pp.

Biggs, A. R., \& Northover, J. (1988a): Early and late-season susceptibility of peach fruits to Monilinia fructicola. Plant Disease, 72: 1070-1074.

Biggs, A. R., \& Northover, J. (1988b): Influence of temperature and wetness duration on infection of peach and sweet cherry fruits by Monilinia fructicola. Phytopathology, 78,: 1352-1356.

Byrde, R. J., \& Willetts, H. J. (1977): The brown rot fungi of fruit. Their biology and control. Oxford: Pergamon.

Emery, K. M., Michailides, T. J., \& Scherm, H. (2000): Incidence of latent infection of immature peach fruit by Monilinia fructicola and relationship to brown rot in Georgia. Plant Disease, 84: 853-857.

Fourie, P. H., \& Holz, G. (2003a): Germination of dry, airborne conidia of Monilinia laxa and disease expression on nectarine fruit. Australasian Plant Pathology, 32: 9-18.
Gell, I., De Cal, A., Torres, R., Usall, J., Melgarejo, P. (2008): Relationship between the incidence of latent infections caused by Monilinia spp. and the incidence of brown rot of peach fruit: factors affecting latent infection. European Journal of Plant Pathology 121: 487-498.

Holb I. J. (2003a): Analyses of temporal dynamics of brown rot development on fruit in organic apple production. International Journal of Horticultural Science, 9 (3-4): 97-100.

Holb I. J. (2003b): The brown rot fungi of fruit crops (Monilinia spp.) I. Important features of their biology (Review paper). International Journal of Horticultural Science, 9 (3-4): 23-36.

Holb IJ, Balla B, Abonyi F, Fazekas M, Lakatos P \& Gáll, JM (2011): Development and evaluation of a model for management of brown rot in organic apple orchards. European Journal of Plant Pathology, 129: 469-483.

Holb, I.J., \& Scherm, H. (2007): Temporal dynamics of brown rot in different apple management systems and importance of dropped fruit for disease development. Phytopathology, 97: 1004-1111.

Holb, I.J., \& Scherm, H. (2008): Quantitative relationships between different injury factors and development of brown rot caused by Monilinia fructigena in integrated and organic apple orchards. Phytopathology, 98; 79-86.

Holb, I.J., \& Schnabel G (2005): Comparison of fungicide treatments combined with sanitation practices on brown rot blossom blight incidence, phytotoxicity, and yield for organic sour cherry production. Plant Disease, 89: 1164-1170.

Hong, C. X., Michailides, T. J., \& Holtz, B. A. (1998): Effects of wounding, inoculum density, and biological control agents on postharvest brown rot of stone fruits. Plant Disease, 82: 1210-1216.

Larena, I., Torres, R., De Cal, A., Liñan, M., Melgarejo, P., Domenichini, P., (2005): Biological control of postharvest brown rot (Monilinia spp.) of peaches by field applications of Epicoccum nigrum. Biological Control, 32: 305-310.

Luo Y. \& Michailides, T. J. (2001): Risk analysis for latent infection of prune by Monilinia fructicola in California. Phytopathology, 91 (12): 1197-1208.

Luo, Y., Ma, Z. \& Michailides, T. J. (2001a): Analysis of factors affecting latent infection and sporulation of Monilinia fructicola on prune fruit. Plant Disease, 85: 999-1003.

Luo, Y., Morgan, D. P. \& Michailides, T. J. (2001b): Risk analysis of brown rot blossom blight of prune caused by Monilinia fructicola. Phytopathology, 91 (8): 759-768.

Northover, J., \& Cerkauskas, R. F. (1994): Detection and significance of symptomless latent infections of Monilinia fructicola in plums. Canadian Journal of Plant Pathology, 16: 30-36.

van Leeuwen, G., Stein, A., Holb, I., \& Jeger, M. (2000): Yield loss in apple caused by Monilinia fructigena (Aderh. \& Ruhl.) Honey, and spatio-temporal dynamics of disease development. European Journal of Plant Pathology, 196: 519-528.

Xu, X. -M., Bertone, C., \& Berrie, A. (2007): Effects of wounding, fruit age and wetness duration on the development of cherry brown rot in the UK. Plant Pathology, 56: 114-119.

Xu, X. M., \& Robinson, J. D. (2000): Epidemiology of brown rot (Monilinia fructigena) on apple: infection of fruits by conidia. Plant Pathology, 49: 201-206. 